ORNL/TM-2015/469

\title{
Tensile and Toughness Assessment of The Procured Advanced Alloys
}

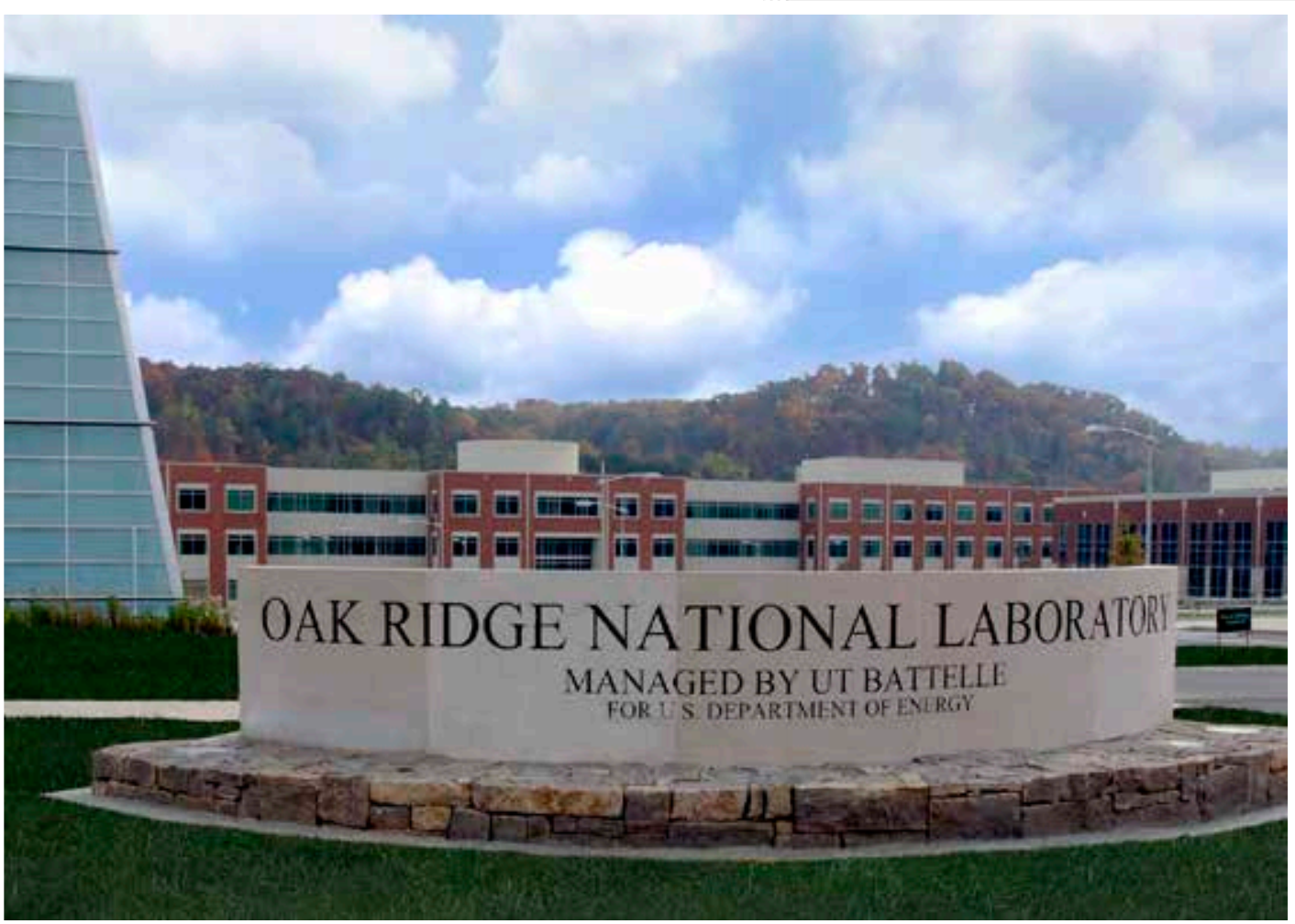

Lizhen Tan

Mikhail A. Sokolov

David T. Hoelzer

Jeremy T. Busby

September 11, 2015 


\section{DOCUMENT AVAILABILITY}

Reports produced after January 1, 1996, are generally available free via US Department of Energy (DOE) SciTech Connect.

Website http://www.osti.gov/scitech/

Reports produced before January 1, 1996, may be purchased by members of the public from the following source:

National Technical Information Service

5285 Port Royal Road

Springfield, VA 22161

Telephone 703-605-6000 (1-800-553-6847)

TDD 703-487-4639

Fax 703-605-6900

E-mail info@ntis.gov

Website http://www.ntis.gov/help/ordermethods.aspx

Reports are available to DOE employees, DOE contractors, Energy Technology Data Exchange representatives, and International Nuclear Information System representatives from the following source:

Office of Scientific and Technical Information

PO Box 62

Oak Ridge, TN 37831

Telephone 865-576-8401

Fax 865-576-5728

E-mail reports@osti.gov

Website http://www.osti.gov/contact.html

This report was prepared as an account of work sponsored by an agency of the United States Government. Neither the United States Government nor any agency thereof, nor any of their employees, makes any warranty, express or implied, or assumes any legal liability or responsibility for the accuracy, completeness, or usefulness of any information, apparatus, product, or process disclosed, or represents that its use would not infringe privately owned rights. Reference herein to any specific commercial product, process, or service by trade name, trademark, manufacturer, or otherwise, does not necessarily constitute or imply its endorsement, recommendation, or favoring by the United States Government or any agency thereof. The views and opinions of authors expressed herein do not necessarily state or reflect those of the United States Government or any agency thereof. 
Light Water Reactor Sustainability (LWRS) Program

\title{
TENSILE AND TOUGHNESS ASSESSMENT OF THE PROCURED ADVANCED ALLOYS
}

\author{
Lizhen Tan, Mikhail A. Sokolov, David T. Hoelzer, Jeremy T. Busby
}

Date Published: September 11, 2015

\section{Prepared by}

OAK RIDGE NATIONAL LABORATORY

Oak Ridge, Tennessee 37831-6283

managed by

UT-BATTELLE, LLC

for the

US DEPARTMENT OF ENERGY

under contract DE-AC05-00OR22725 



\section{CONTENTS}

\section{Page}

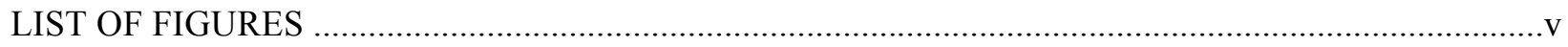

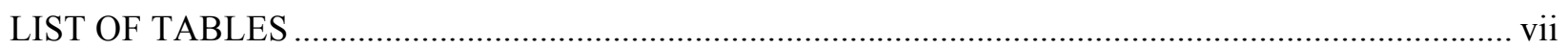

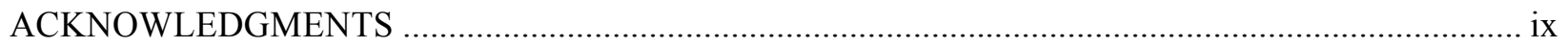

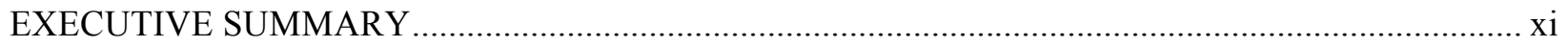

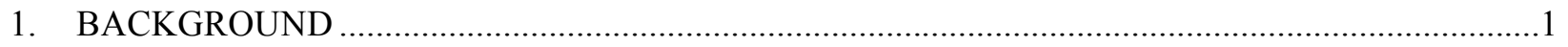

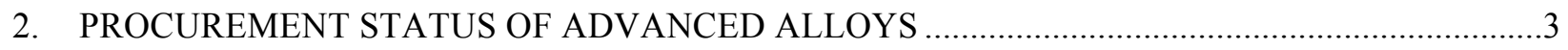

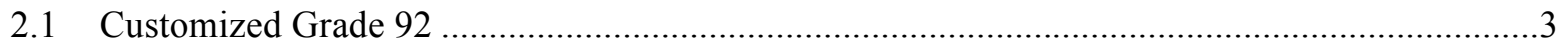

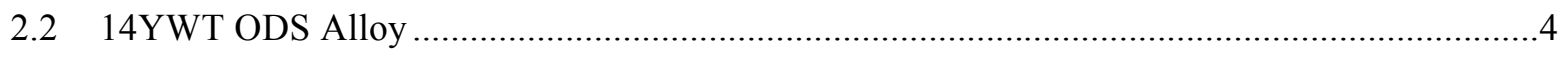

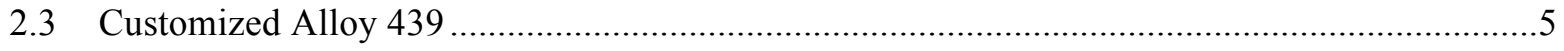

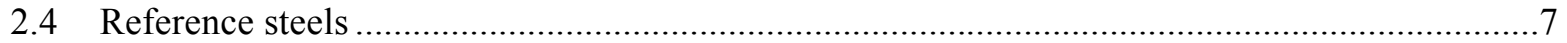

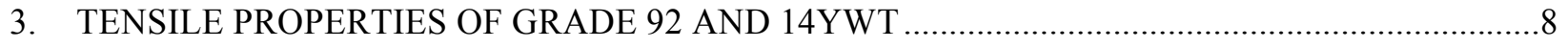

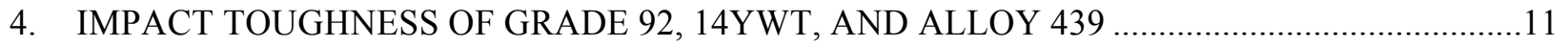

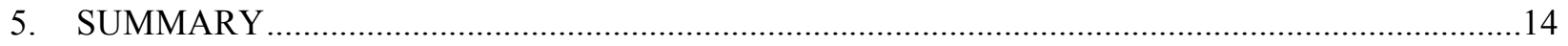

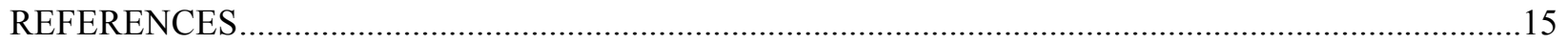





\section{LIST OF FIGURES}

Figure

Figure 1. Optical image of heat 011448 at the transverse-normal $(\mathrm{TN})$ direction.....................................3

Figure 2. (a) SEI showing arrow-pointed pores (LN: longitudinal-normal); (b) BEI showing stringers of small dark particles (LT: longitudinal-transverse); (c) BEI showing bimodal grain size with a packet of large grains elongated in the extrusion direction (LN). Longitudinal and transverse directions are corresponding to the extrusion and crossrolling directions, respectively.

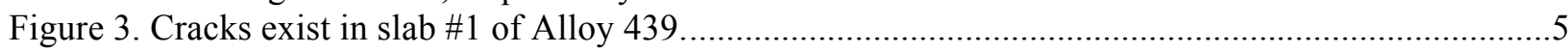

Figure 4. Optical images of warm-rolled Alloy 439 samples at $500^{\circ} \mathrm{C}$ (left) and $300^{\circ} \mathrm{C}$ (right) followed by annealing at $950^{\circ} \mathrm{C}$ for $10 \mathrm{~min}$.

Figure 5. Vickers hardness of Alloy 439 samples in the conditions of as-received and warm-rolled at $750,650,500$, and $300^{\circ} \mathrm{C}$.

Figure 6. EBSD image quality maps of the AOD316L and ESR316L, in which delta ferrite is highlighted in red.

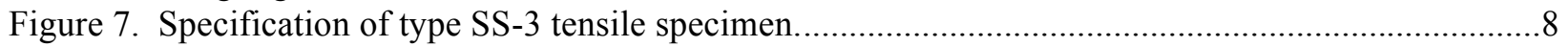

Figure 8. Yield strength, tensile strength, uniform elongation, and total elongation of customized Grade 92.

Figure 9. Yield strength, tensile strength, uniform elongation, and total elongation of 14YWT. ..............9

Figure 10. Yield strength comparison of the selected commercial and advanced alloys at $300^{\circ} \mathrm{C} \ldots \ldots \ldots \ldots 10$

Figure 11. Specification of half-size Charpy V-notch impact specimen. ...............................................11

Figure 12. Charpy impact data of customized Grade 92 showing DBTT curves. ....................................12

Figure 13. Charpy impact data of 14YWT showing a DBTT curve ......................................................12

Figure 14. Charpy impact data of the as-received Alloy 439 showing uncertain DBTT curves...............13 



\section{LIST OF TABLES}

\section{Table}

Page

Table 1. Identified commercial, advanced, and reference alloys to be tested in the ARRM program .........2

Table 2. Procurement status of advanced alloys for the ARRM program ….............................................

Table 3. Chemical analysis results (wt $\%$ ) of the 14YWT ODS alloy at different stages. ..........................

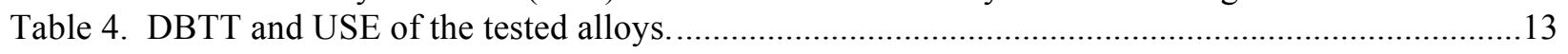





\section{ACKNOWLEDGMENTS}

This research was sponsored by the U.S. Department of Energy, Office of Nuclear Energy, for the Light Water Reactor Sustainability (LWRS) program Research and Development effort.

The authors are grateful to Raj Pathania of Electric Power Research Institute (EPRI) and Larry Nelson of JLN Consulting for their organizing and coordinating the Advanced Radiation Resistant Materials (ARRM) program, Martin Morra of General Electric (GE) for helpful discussion and sharing/connecting industrial vendors, Eric Manneschmidt, Tom Geer, David Harper, Gregory Cox, and Brian Sparks of ORNL for preparing and testing the samples, and Brandon Blamer (Summer-intern from Texas A\&M University) for assistance on some of the sample characterization. Chinthaka Silva of ORNL is also appreciated for reviewing this report. 



\section{EXECUTIVE SUMMARY}

Life extension of the existing nuclear reactors imposes irradiation of high fluences to structural materials, resulting in significant challenges to the traditional reactor materials such as type 304 and 316 stainless steels. Advanced alloys with superior radiation resistance will increase safety margins, design flexibility, and economics for not only the life extension of the existing fleet but also new builds with advanced reactor designs. The Electric Power Research Institute (EPRI) teamed up with Department of Energy (DOE) to initiate the Advanced Radiation Resistant Materials (ARRM) program, aiming to develop and test degradation resistant alloys from current commercial alloy specifications by 2021 to a new advanced alloy with superior degradation resistance by 2024 in light water reactor (LWR)-relevant environments.

A total of sixteen downselected commercial and advanced alloys have being procured for testing under the ARRM program. EPRI-GE (General Electric) is leading the procurement of eleven commercial alloys, out of which nine have been already procured. Oak Ridge National Laboratory (ORNL) is leading the procurement of advanced alloys, including customized Grade 92, customized alloy 439, 14YWT oxide-dispersion-strengthened (ODS) alloy, and two other alloys that are to be determined in the alloy groups of $12 \mathrm{Cr}$ ferritic-martensitic (FM) steel and high-Cr and high-Al ODS alloy.

The customized Grade 92, in a form of 2"-thick forged plates with a total of 400 lbs. nominal weight, was procured from Carpenter Technology Corporation (CarTech), which have acceptable specifications complying with the relevant ASTM standard. The 14YWT ODS alloy was fabricated at ORNL, yielded six plates in a size of $4.72 " \times 2.76 " \times 0.35$ " per plate with a total weight of $\sim 10 \mathrm{lbs}$. The customized Alloy 439 procured from CarTech has abnormally large grain size, ranging from a few hundreds micrometers at plate surfaces to a couple of millimeters at plate center. Thermomechanical treatment (TMT) by means of warm rolling and annealing has been conducted at ORNL. Section of the as-received 2"-thick Alloy 439 plate was subjected to warm rolling to $0.8^{\prime}$ "-thick at $300^{\circ} \mathrm{C}$ followed by annealing at $950^{\circ} \mathrm{C}$, which yielded full recrystallization approximately, leading to $\sim 100 \mu \mathrm{m}$ uniaxial grain size across plate thickness and slightly reduced hardness. Application of isothermal forging to the as-received Alloy 439 plates is being investigated to have uniformly refined grains and to approximately retain original 2" thickness. Additionally, reference alloys type 316L stainless steel and T91 FM steel were procured. The acceptable quality of type $316 \mathrm{~L}$ stainless steel to be tested under the ARRM program was determined in terms of the limit of delta ferrite content (for concerns of phase stability under irradiation, weldability, etc.) and grain size uniformity.

Tensile tests were conducted on the procured Grade 92 and 14YWT using type SS-3 miniature specimens at a nominal strain rate of $0.001 \mathrm{~s}^{-1}$ and temperatures from room temperature to $\sim 750^{\circ} \mathrm{C}$ following the ASTM standards E8-13a and E21-09. As compared with the customized Grade 92, the 14YWT exhibited similar temperature-dependent tensile behavior, having noticeably higher strength (e.g., $\sim 410 \mathrm{MPa}$ increase at room temperature and $\sim 130 \mathrm{MPa}$ increase at $\sim 750^{\circ} \mathrm{C}$ ), slightly higher uniform elongation (e.g., $\sim 4 \%$ increase at room temperature), and comparable total elongation. The Grade 92 has greater strength than the downselected commercial stainless steels and $\mathrm{Zr}-2.5 \mathrm{Nb}$ alloy at $300^{\circ} \mathrm{C}$, while the 14YWT has strength comparable to the downselected Inconel 725.

Impact toughness of the as-received Grade 92, 14YWT, and Alloy 439 was evaluated using half-size Charpy V-notch specimens in the T-L and L-T orientations at temperatures from $-150^{\circ} \mathrm{C}$ to $300^{\circ} \mathrm{C}$ following the ASTM standard E23-12c. Specimens in the T-L orientation generally exhibited lower upper-shelf energy (USE) and higher ductile-brittle transition temperature (DBTT) than the specimens in the L-T orientation. As compared to the Grade 92, the 14YWT has significantly lower mathematic DBTT 
at $1 / 2 \mathrm{USE}\left(-79.8^{\circ} \mathrm{C}\right.$ of the $14 \mathrm{YWT}$ vs. $-19.7^{\circ} \mathrm{C}$ of the Grade 92$)$, but does not have applicable engineering DBTT at $6.5 \mathrm{~J}$ for this type of subsize specimens because the USE of the 14YWT is $5.0 \mathrm{~J}$ (in contrast to $25.9 \mathrm{~J}$ of the Grade 92). The engineering DBTT of the Grade 92 was $-70^{\circ} \mathrm{C}$ of the T-L specimens. The experimental data of the 14YWT followed a good consistent trend as a function of testing temperature, which may suggest that the observed pores, stringers of small dark particles, and some bimodal grain size distribution in the 14YWT did not result in significant effect on the impact toughness results. The DBTT of the Alloy 439 was not able to be determined yet due to the large variations of the tested specimens, which may be attributable to the limited numbers of grains within the testing ligament of the half-size specimen. The USE of the Alloy 439 was determined to be $\sim 38 \mathrm{~J}$. The effect of grain refinement by the TMT and ongoing isothermal forging on the impact toughness will be pursued in next fiscal year. 


\section{BACKGROUND}

Nuclear power currently provides a significant fraction of the United States' non-carbon emitting power generation. In future years, nuclear power must continue to generate a significant portion of the nation's electricity to meet the growing electricity demand, clean energy goals, and to ensure energy independence. New reactors will be an essential part of the expansion of nuclear power. However, given limits on new builds imposed by economics and industrial capacity, the extended service of the existing fleet will also be required.

Nuclear reactors present a very harsh environment for components service. Components within a reactor core must tolerate high temperatures, water, stress, vibration, and an intense neutron field. With the nominal irradiation temperature of $\sim 290^{\circ} \mathrm{C}$ in light water reactors (LWRs), actual component temperatures range from $270^{\circ} \mathrm{C}$ to $370^{\circ} \mathrm{C}$ depending on the relative position of the component within the reactor core and relative amounts of cooling and gamma heating. Degradation of materials in this environment can lead to reduced performance, and in some cases, sudden failure.

Extending the service life of a reactor will increase the total neutron fluence to each component and may result in irradiation-induced effects not yet observed in LWR conditions, although this form of degradation has been observed in fast reactor conditions. Irradiation-induced processes must be carefully considered for higher fluences, particularly the influence of radiation-induced segregation (RIS), swelling, and/or precipitation on embrittlement. The neutron irradiation field can produce large property and dimensional changes in materials. For LWRs, high temperature embrittlement and creep are not common problems due to the lower reactor temperature. However, radiation embrittlement, phase transformation, segregation, and swelling have all been observed in reactor components. Increases in neutron fluence may exacerbate radiation-induced or -enhanced microstructural and property changes. Comprehensive reviews on radiation effects on the traditional structural materials of LWRs can be found in Ref. [1,2].

It is desirable to have advanced alloys that possess greater radiation resistance than the traditional reactor materials. The use of such advanced alloys in replacing the traditional reactor materials for the extension of the existing fleets and the building of new reactors will bring improved safety margins and economics. To identify and develop advanced radiation resistant materials, Electric Power Research Institute (EPRI) has teamed up with Department of Energy (DOE) to initiate an Advanced Radiation Resistant Materials (ARRM) program. The EPRI report of "Critical Issues Report and Roadmap for the Advanced Radiation-Resistant Materials Program" [3] reviewed the current commercial and advanced alloys that are applicable as core structural materials of LWRs and laid out a detailed research plan to meet the goal of the program. A number of alloys were down-selected as candidate materials to be tested in the ARRM program, managed by Drs. R. Pathania of EPRI and J.T. Busby of Oak Ridge National Laboratory (ORNL). Procurement of high quality alloys of the candidate materials is essential to successfully implement the program. The alloy procurement processes have followed the EPRI-ARRM materials procuring guidance, ORNL Quality Assurance process equivalent to ASME NQA-1 standard, and ASTM standards that are relevant to specific alloys and testing methods. The identified alloys that are to be procured are classified into two categories, i.e., commercial alloys and advanced alloys, listed in Table 1. Commercial reference alloys are also listed in Table 1. EPRI and General Electric (GE) are leading the procurement of the commercial alloys. ORNL is leading the procurement of the advanced alloys and reference alloys. The procured alloys are examined in terms of chemistry homogeneity, microstructural uniformity, and basic mechanical properties to justify their qualities according to relevant ASTM standards. 
Table 1. Identified commercial, advanced, and reference alloys to be tested in the ARRM program

\begin{tabular}{|c|c|}
\hline $\begin{array}{l}\text { Ni-base } \\
\text { Austenitic } \\
\text { Others }\end{array}$ & $\begin{array}{l}\text { Commercial Alloys } \\
\text { C22, 690, 625, 625-plus (age hardened), X-750, 725, } 718 \\
800,309 / 310 \\
\text { Zr-2.5Nb, Ti alloys (Grade } 26 \text { with } 0.1 \mathrm{Ru} \text { ) } \\
\end{array}$ \\
\hline $\begin{array}{l}\text { 9Cr FM } \\
12 \mathrm{Cr} F M \\
\text { High-Cr }(>14 \mathrm{Cr}) \text { Ferritic } \\
\text { 9-14Cr ODS } \\
\text { High-Cr\&Al ODS } \\
\end{array}$ & $\begin{array}{l}\text { Advanced Alloys } \\
\text { Grade } 92 \\
\text { To be determined, e.g., HT-9, HCM12A } \\
439 \\
14 \mathrm{YWT} \\
\text { To be determined, e.g., PM2000, MA956, 16-ODS } \\
\end{array}$ \\
\hline Austenitic & $\begin{array}{l}\text { Reference Alloys } \\
316 \mathrm{~L}\end{array}$ \\
\hline
\end{tabular}




\section{PROCUREMENT STATUS OF ADVANCED ALLOYS}

Table 2 summarizes the procurement status of advanced alloys and reference alloy for the ARRM program. Among the five groups of advanced alloys, two alloys are to be determined (TBD) from the alloy groups of 12Cr FM and high-Cr\&Al ODS alloy, respectively. The customized Grade 92 and alloy 439, fabricated by means of vacuum induction melting (VIM), electro-slag remelting (ESR), and hot forging, have been procured from Carpenter Technology (CarTech). Each alloy has a nominal weight of $400 \mathrm{lbs}$. and in the form of plates (2"-thick by 6"-wide). In addition, type T91 and T92 FM steels and 316L austenitic stainless steel were procured from Nippon Steel \& Sumitomo Metal Corporation (NSSMC) of Japan and North American Stainless, which will be used as reference steels for the tests of the advanced and commercial alloys under the ARRM program.

Table 2. Procurement status of advanced alloys for the ARRM program

\begin{tabular}{|c|c|c|c|c|}
\hline Group & Alloy Group & Identified Alloy & Producer & Received Time \\
\hline \multirow{5}{*}{ Advanced } & 9Cr FM & Customized Grade 92 & CarTech & May 2014 \\
\hline & $12 \mathrm{Cr} F M$ & TBD & & \\
\hline & High-Cr FM (>14Cr) & Customized Alloy 439 & CarTech & March 2014 \\
\hline & 9-14Cr ODS & 14YWT & ORNL & May 2014 \\
\hline & High-Cr\&Al ODS & TBD & & \\
\hline \multirow[t]{2}{*}{ Reference } & FM & T91 and T92 & NSSMC & May 2014 \\
\hline & Austenitic & $316 \mathrm{~L}$ & North American Stainless & September 2014 \\
\hline
\end{tabular}

\subsection{Customized Grade 92}

Two heats of customized Grade 92 were procured. Heat 011448 was only melted by VIM and showed good chemistry homogeneity. In contrast, heat 011442 was melted with VIM followed by ESR. The ESR process resulted in noticeable reductions in the amounts of $\mathrm{Si}, \mathrm{Nb}, \mathrm{N}$, and $\mathrm{B}$ in heat 011442. Therefore, the study has been primarily conducted on heat 011448 . The heat were subjected to normalization at $1130^{\circ} \mathrm{C}$ for $0.5 \mathrm{~h}$, followed by tempering at $600^{\circ} \mathrm{C}$ for $1 \mathrm{~h}$ and $750^{\circ} \mathrm{C}$ for $4 \mathrm{~h}$ to achieve a balanced Charpy impact resistance and strength at room temperature, e.g., $\sim 220 \mathrm{~J}$ absorbed Charpy impact energy and 262 HV1 [4]. Metallographic microstructural characterization (e.g., Figure 1) showed tempered martensite uniformly developed in prior-austenite grain size of about 30-50 $\mu \mathrm{m}$, comparable to conventional Grade 92, which indicates that the increased normalization temperature at $1130^{\circ} \mathrm{C}$ did not remarkably increase the prior-austenite grain size.

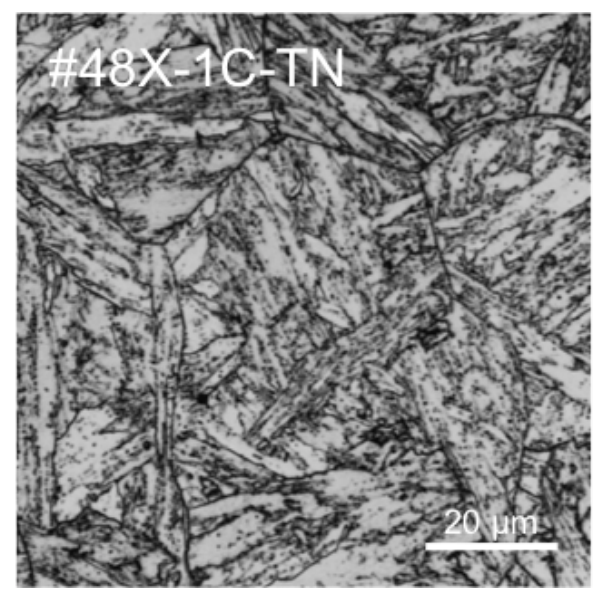

Figure 1. Optical image of heat 011448 at the transverse-normal (TN) direction. 


\subsection{YWT ODS Alloy}

The 14YWT ODS alloy ( 10 lbs.), renamed as FCRD-NFA1 recently, was produced by extruding ball-milled powder at $850^{\circ} \mathrm{C}$ and cross rolling to $50 \%$ thickness reduction at ORNL. The plates were produced using the "best practice" processing conditions developed in the FCRD Advanced Fast Reactor Cladding Program and the extrusion and rolling conditions developed over the past 12 years at ORNL from producing numerous heats of the advanced 14YWT ODS ferritic alloy. The canning material, containing the ball-milled powder, was finally removed to reveal the embedded 14YWT alloy, yielding six plates in a size of approximately $4.75 " \times 2.75 " \times 0.35$ " each.

Chemical analyses were conducted at different stages during the fabrication of the 14YWT alloy, i.e., pre-alloyed powder by argon gas atomization at ATI Powder Metals, ball-milled powder at the pilot facility of Zoz in Wenden of Germany (e.g., the lot V540-02 used for producing the FCRD-NFA1 heat), and the finally produced plates. The chemistry of the plate was analyzed by Evans Analytical Group (EAG) of U.S. The results of the chemical analyses in weight percentage (wt\%) are listed in Table 3. Noticeable variations were observed for $\mathrm{O}$ and $\mathrm{C}$. The presence of $\mathrm{Cu}$ in the final plate might be from the ball-milling and prior hot-extrusion processes.

Table 3. Chemical analysis results (wt\%) of the 14YWT ODS alloy at different stages.

\begin{tabular}{ccccccccc}
\hline Sample & $\mathrm{Cr}$ & $\mathrm{W}$ & $\mathrm{Ti}$ & $\mathrm{Y}$ & $\mathrm{O}$ & $\mathrm{C}$ & $\mathrm{N}$ & $\mathrm{Cu}$ \\
\hline $\begin{array}{c}\text { Pre-alloyed powder (ATI } \\
\text { Powder Metals) }\end{array}$ & 13.8 & 3.0 & 0.37 & 0.21 & 0.012 & & & \\
$\begin{array}{c}\text { Ball-milled powder (V540-02, } \\
\text { Zoz, Wenden, Germany) } \\
\text { Plate }\end{array}$ & 12.77 & 2.95 & 0.38 & 0.22 & 0.125 & 0.014 & 0.007 & \\
\hline & 14.1 & 2.83 & 0.36 & 0.217 & 0.0054 & 0.0043 & 0.0058 & 0.156 \\
\hline
\end{tabular}

Microstructural characterization using scanning electron microscopy (SEM) in the secondary electron imaging (SEI) and backscattered electron imaging (BEI) modes revealed the primary features of the material, such as few pores, some stringers of small dark particles $(\sim 20-150 \mathrm{~nm})$, and occasional bimodal grain size distribution as shown in Figure 2. The stringers showed wavy patterns independent of grain boundaries and were not aligned preferentially with either the extrusion or rolling directions. The grains appeared nearly equiaxed without significant elongation in either the extrusion (longitudinal) or crossrolling (transverse) directions. The average grain size is about $0.79 \mu \mathrm{m}$.
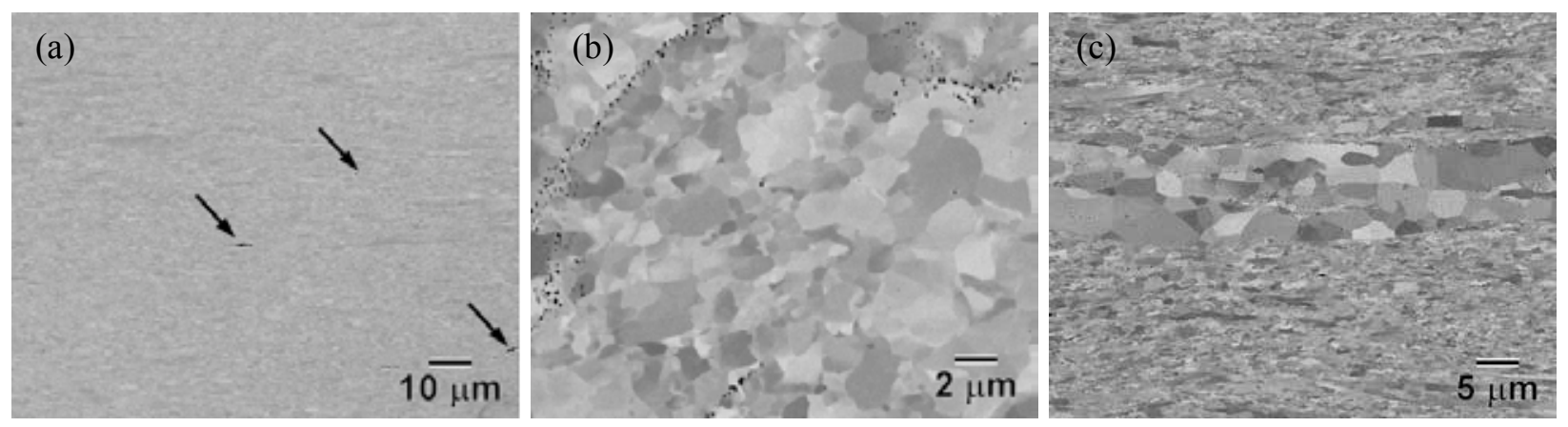

Figure 2. SEM micrographs of 14YWT ODS alloy: (a) SEI showing arrow-pointed pores (LN: longitudinalnormal); (b) BEI showing stringers of small dark particles (LT: longitudinal-transverse); (c) BEI showing bimodal grain size with a packet of large grains elongated in the extrusion direction (LN). Longitudinal and transverse directions are corresponding to the extrusion and cross-rolling directions, respectively. 


\subsection{Customized Alloy 439}

The as-received alloy 439 , heat 011438 , exhibited satisfactory chemistry and hardness according to the ASTM A240-13a. However, the grain size across plate thickness ranges from $\sim 200 \mu \mathrm{m}$ at surfaces to about 1-2 mm at plate center, which is similar to the commercial alloy 439 products, usually in sheet form. To obtain refined grains with much smaller size variations, different thermomechanical treatments (TMTs) are being explored. One of the TMTs is using isothermal forging that is being pursued at Wyman Gordon. The first plate (slab \#1) was not suitable for further processing using isothermal forging because of the presence of cracks as shown in Figure 3. The cracks primarily exist in center of the plate, which transgranularly propagate inside the large grains. Such cracks were not observed in metallographic study of slabs \#4 and \#5 [4], which were hot-forged from $1093^{\circ} \mathrm{C}$, a lower temperature than that used for slabs $\# 1$ and $\# 2$ from $1250^{\circ} \mathrm{C}$. Therefore, slabs $\# 4$ and $\# 5$ have been sent to Wyman Gordon for isothermal forging process.

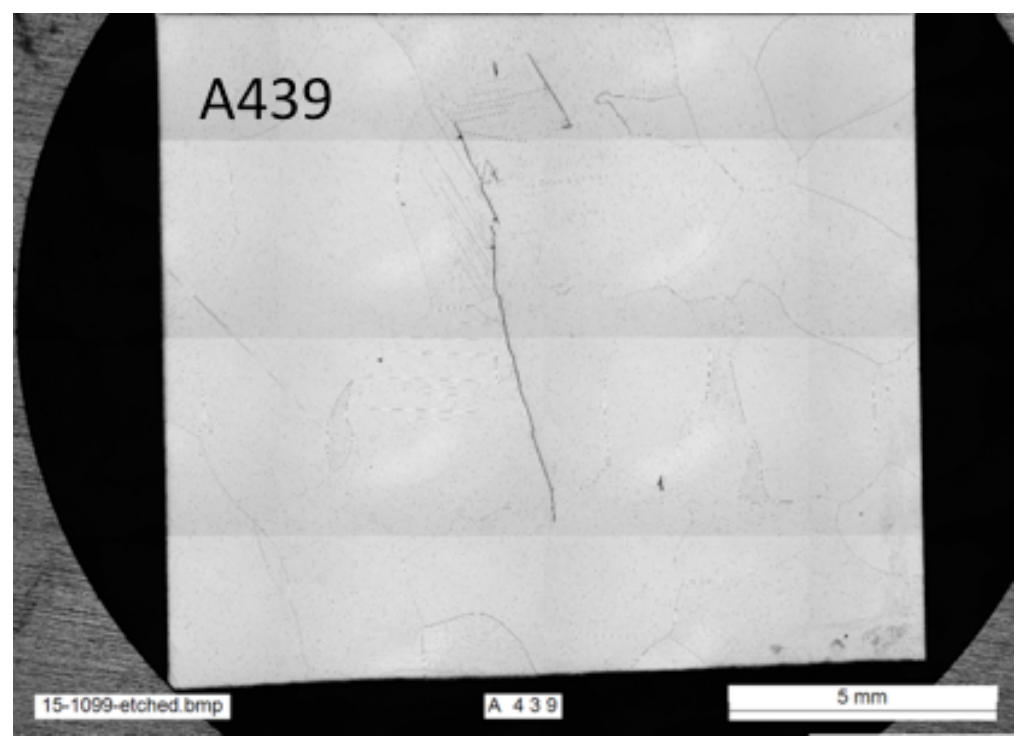

Figure 3. Cracks exist in slab \#1 of Alloy 439.

The other type of TMT of interest is conventional hot rolling and annealing processes to promote recrystallization in the as-received Alloy 439 plates, which are being studied at ORNL. Warm-rolling to $0.8^{\prime \prime}$-thickness at 750,650 , and $500^{\circ} \mathrm{C}$, followed by final annealing at $950^{\circ} \mathrm{C}$ for $10 \mathrm{~min}$ was applied to small sections of Alloy 439 in last fiscal year. Microstructural characterization indicated that warmrolling at lower temperatures significantly increased recrystallization fraction. To achieve fully recrystallized microstructure, warm-rolling at $300^{\circ} \mathrm{C}$ has been conducted in this fiscal year. The crossthickness optical micrographs are shown in Figure 4, with the horizontal and vertical directions of the images corresponding to the plate thickness and rolling directions, respectively. The sample rolled at $500^{\circ} \mathrm{C}$ shows many recrystallization fine grains interwoven with a few large grains that did not undergo full recrystallization. In comparison, the sample rolled at $300^{\circ} \mathrm{C}$ shows approximately fully recrystallized fine grains with size about $100 \mu \mathrm{m}$. The adjacent refined grains have similar contrast, which approximately followed the grain orientations of the initial large grains. The grains with higher contrast contain dense sub-micrometer size dark particles. Detailed microstructural characterization will be conducted to see the differences of the grains with variant contrast and their possible correlations on the formation of particles. 

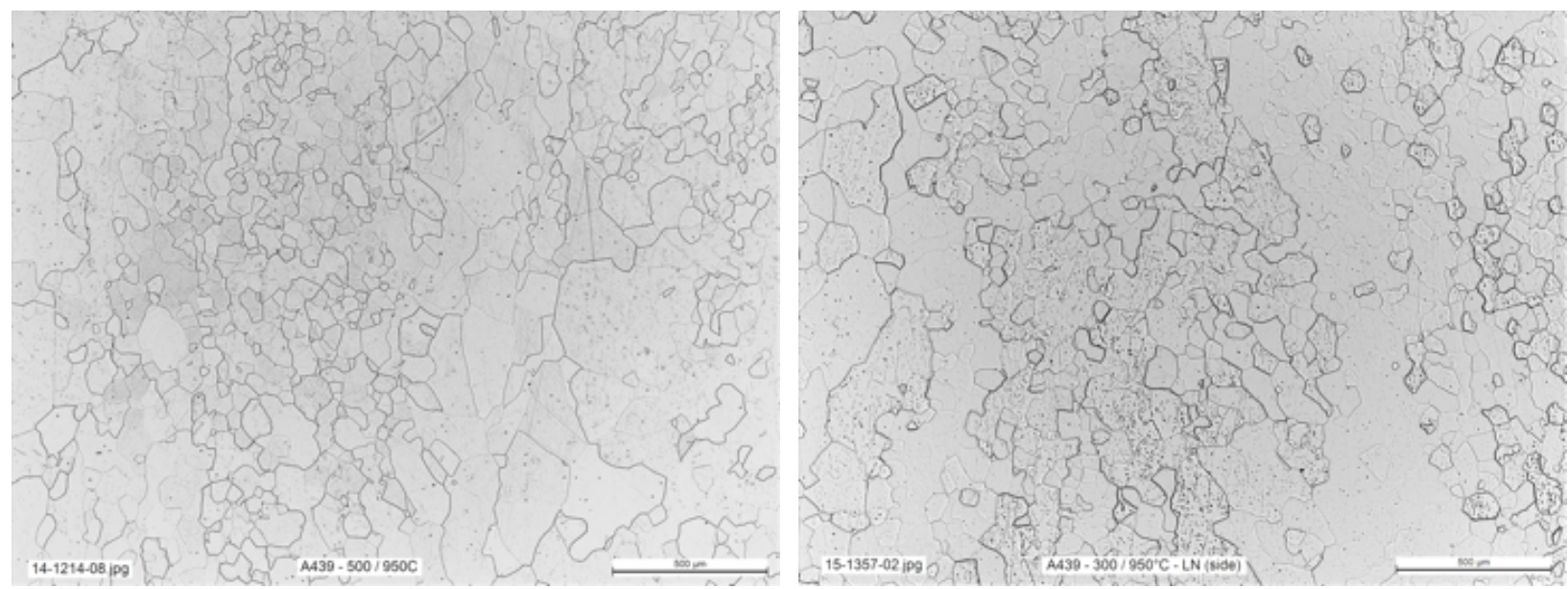

Figure 4. Optical images of warm-rolled Alloy 439 samples at $500^{\circ} \mathrm{C}$ (left) and $300^{\circ} \mathrm{C}$ (right) followed by annealing at $950^{\circ} \mathrm{C}$ for $10 \mathrm{~min}$.

Vickers hardness of the alloy 439 samples in the as-received (AR) and the warm-rolled conditions was measured using a load of $1 \mathrm{kgf}$. The statistical results, average of five measurements of each sample, are plotted in Figure 5. Little recrystallization was occurred in the $750^{\circ} \mathrm{C}$ warm-rolled sample, leading to noticeable increases in hardness as compared to the AR condition. The lower temperature warm-rolling increased the fraction of recrystallization, leading to the decreases of hardness reaching a plateau. The larger standard deviation of the $300^{\circ} \mathrm{C}$ warm-rolled sample is likely due to the different distribution of the particles in the sample as shown in Figure 4 (right). The hardness results of all the sample conditions satisfy the requirement of $<180 \mathrm{HV}$ for Alloy 439 specified in the ASTM A240-13a.

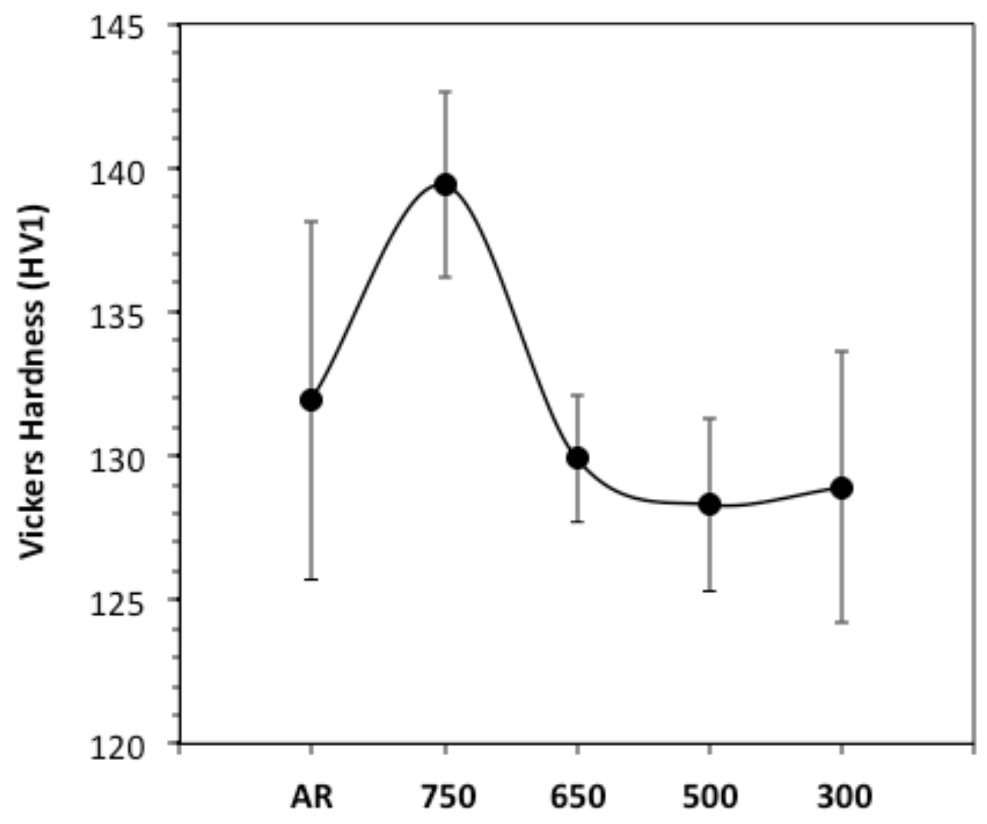

Figure 5. Vickers hardness of Alloy 439 samples in the conditions of as-received and warm-rolled at 750,650 , 500 , and $300^{\circ} \mathrm{C}$. 


\subsection{Reference steels}

A heat of type 316L stainless steel plate (1"-thick) was procured in last fiscal year, which was melted by electric arc furnace (EAF) and followed by argon oxygen decarburization (AOD) and continuous casting. This heat is not qualified for tests under the ARRM program because of the presence of noticeable amount of delta ferrite phase in the alloy. Figure 6 (left) shows electron backscatter diffraction (EBSD) data in image quality map of the AOD316L. Delta ferrite is highlighted in red, showing two types of morphologies. One type is in line shape allotriomorphic ferrite, primarily along with grain boundaries. The other is Widmanstatten ferrite, growing into individual grains, which has less population than the line shape ferrite. For comparison, a small section of another heat of $316 \mathrm{~L}$, re-melted by electroslag remelting (ESR), was characterized using the same technique. The result in Figure 6 (right) shows a few small allotriomorphic ferrite grains, which are significantly less than the AOD316L. However, there are some unrecrystallized large grains in this heat, e.g., the one on right of the image in Figure 6 (right), which may result in inhomogeneous mechanical properties. Further study of the procured heats is in progress. A new heat of 316L has been shared by Knolls atomic power laboratory (KAPL), which has shown acceptable quality for tests under the ARRM program after removing a decent amount of the surface material.
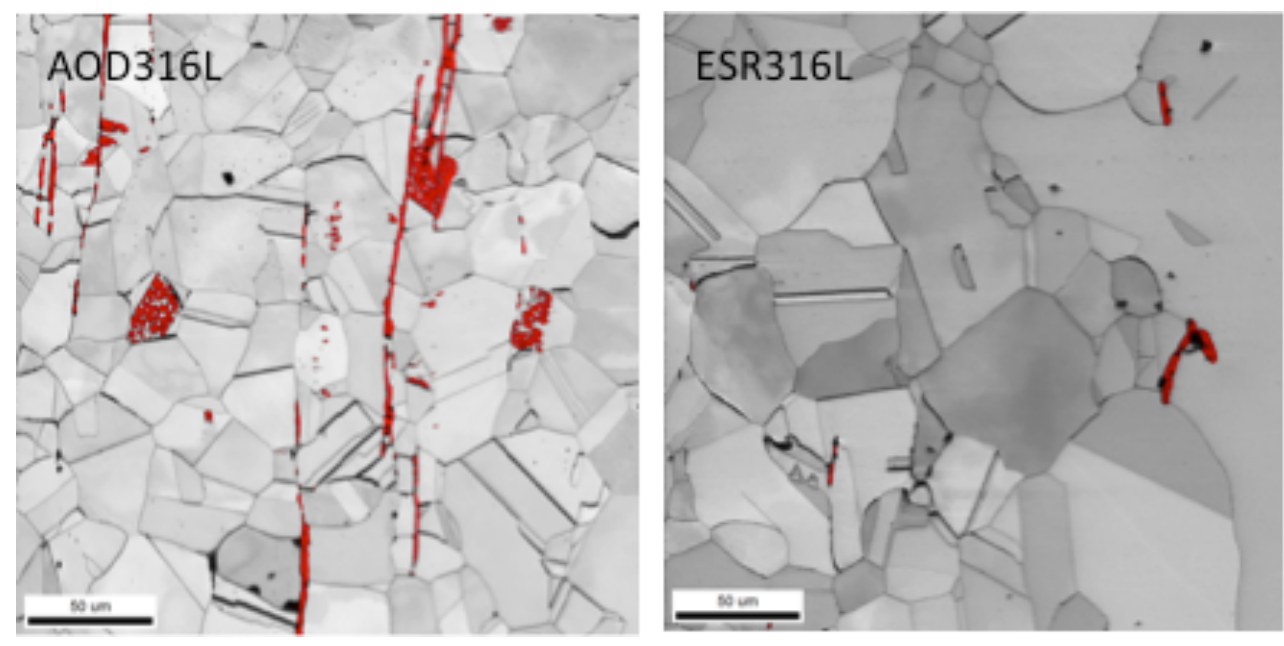

Figure 6. EBSD image quality maps of the AOD316L and ESR316L, in which delta ferrite is highlighted in red.

In addition, some commercial T91 and T92 (tube form) were procured from Nippon Steel \& Sumitomo Metal Corporation (NSSMC) of Japan to be served as reference steel for FM steels. The T91 and T92 heats are in a form of 1-1/4" outer diameter with a 1/4" wall thickness. 


\section{TENSILE PROPERTIES OF GRADE 92 AND 14YWT}

Type SS-3 miniature specimens were used to screen the tensile properties of the procured customized Grade 92 (heat 011448) and 14YWT ODS alloy. The geometry of this type of specimens is shown in Figure 7. The specimens were machined with specimen length parallel to the longitudinal direction of heat 011448 and extrusion direction of 14YWT. Tensile testing was conducted in air at temperatures from ambient temperature up to $\sim 750^{\circ} \mathrm{C}$ in accordance with the ASTM Standards E8/E8M-13a, "Standard test methods for tension testing of metallic materials" and E21/E21M-09, "Standard test methods for elevated temperature tension tests of metallic materials." Tests were performed using an MTS tensile testing system with a load cell possessing $22 \mathrm{kN}(5,000 \mathrm{lbf})$ capacity, which is integrated in the load train and placed in the water-cooled zone below the hot zone of the furnace. Due to the small specimen size, an exensometer was not used during the tests. Tensile testing was performed at a crosshead speed of $0.0076 \mathrm{~mm} / \mathrm{s}(0.018 \mathrm{in} / \mathrm{min})$, corresponding to a nominal strain rate of $0.001 \mathrm{~s}^{-1}$. The tensile testing system, load cells, and furnace thermocouples were regularly calibrated.

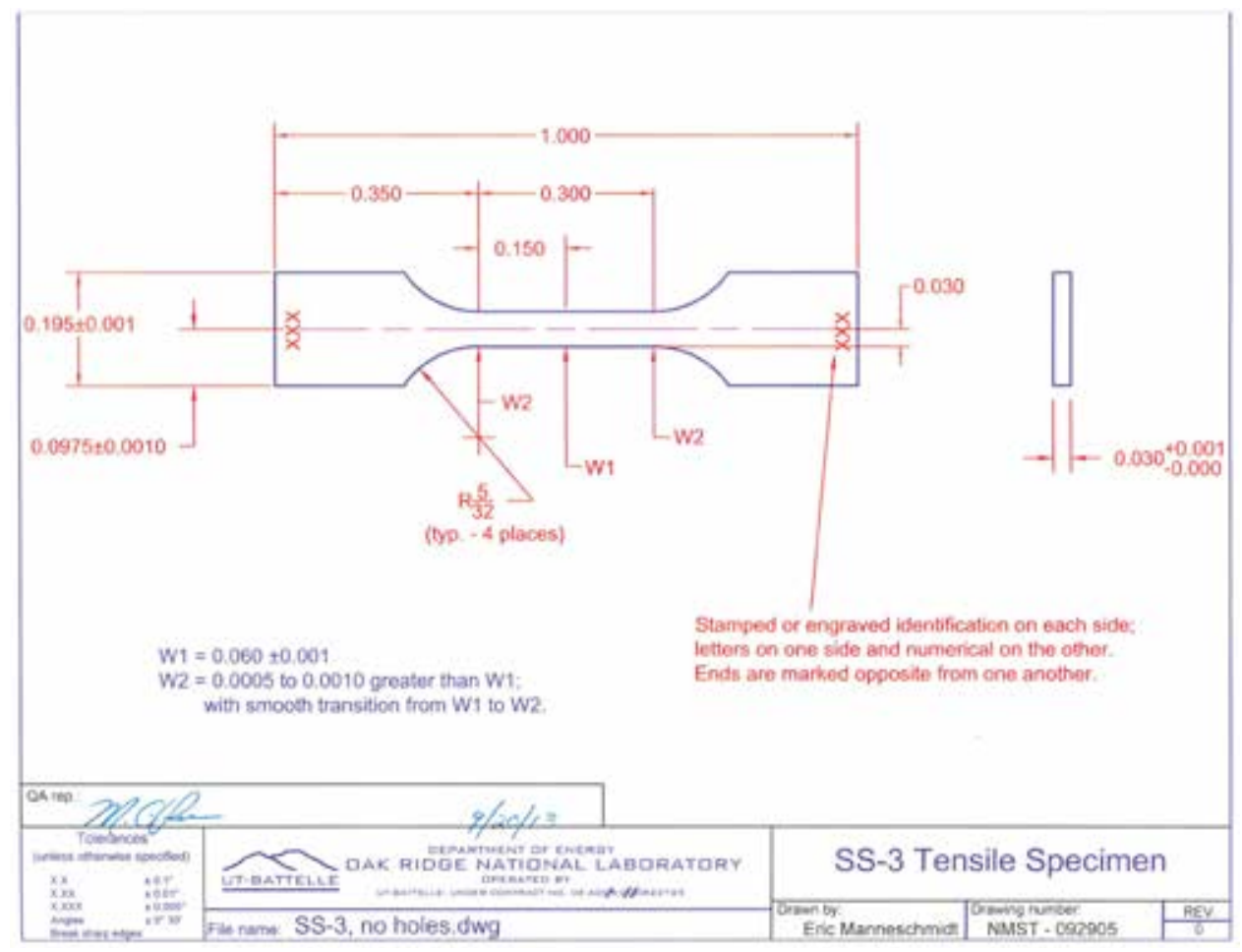

Figure 7. Specification of type SS-3 tensile specimen.

Figure 8 plots the yield strength, tensile strength, uniform elongation, and total elongation of the customized Grade 92 tested at temperatures from room temperature to about $750^{\circ} \mathrm{C}$. The measured yield and tensile strength of the customized Grade 92 at room temperature is significantly greater $(\sim 300 \mathrm{MPa})$ than the minimum yield (440 MPa) and tensile (620 MPa) strength specified in the ASTM A335-11, "Standard specification for seamless ferritic alloy-steel pipe for high-temperature service." The strength decreased to $100-150 \mathrm{MPa}$ as the testing temperature increased to $\sim 750^{\circ} \mathrm{C}$. The uniform elongation followed a similar trend, which decreased with increasing temperature from $9.2 \%$ at room temperature to a saturated level of $\sim 3.9 \%$ at $\sim 550-750^{\circ} \mathrm{C}$. In contrast, the total elongation decreased from $18.3 \%$ at room temperature to a minimum value of $12.9 \%$ at $\sim 400^{\circ} \mathrm{C}$ and then increased to $21.7 \%$ at $\sim 750^{\circ} \mathrm{C}$. The 
total elongation at room temperature satisfies the ASTM A335-11 with the minimum total elongation requirement of $E=32 t+10.00=10.96 \%$ for such a miniature specimen with $t=0.03 \%$.

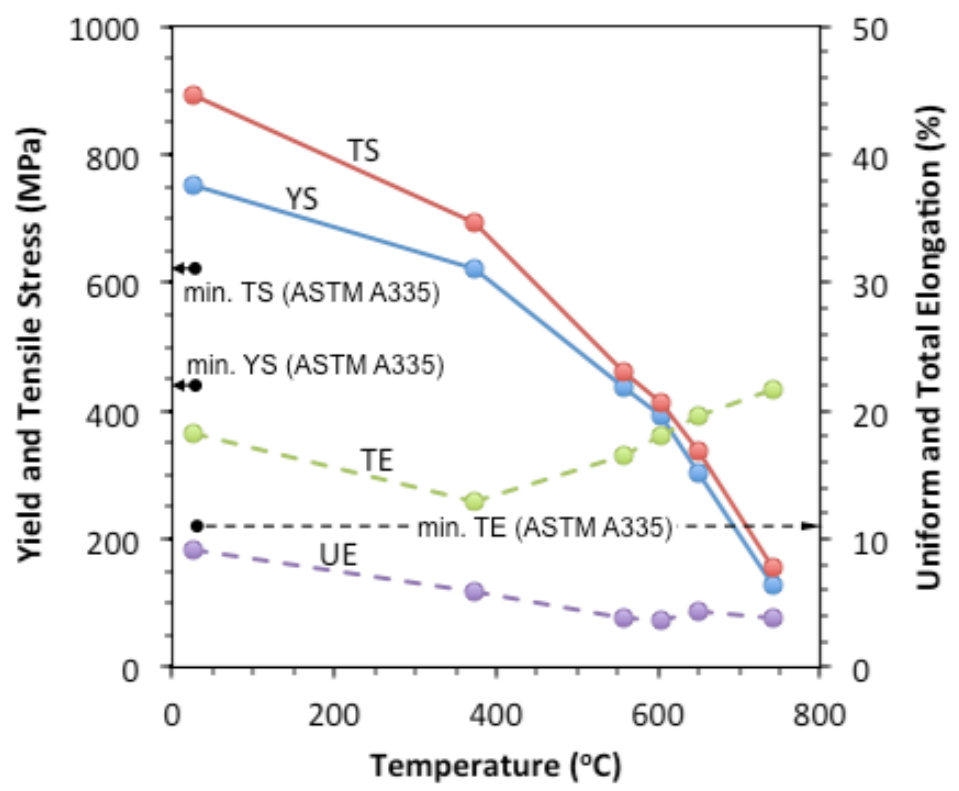

Figure 8. Yield strength, tensile strength, uniform elongation, and total elongation of customized Grade 92.

The same type of tensile tests were conducted on the 14YWT ODS alloy with the results plotted in Figure 9. The 14YWT ODS alloy exhibited similar temperature-dependent tensile behavior as the customized Grade 92 in Figure 8. As compared to the customized Grade 92, the 14YWT ODS alloy exhibited noticeably higher strength (e.g., $\sim 410 \mathrm{MPa}$ at room temperature and $\sim 130 \mathrm{MPa}$ at $\sim 750^{\circ} \mathrm{C}$ ), slightly higher uniform elongation (e.g., $\sim 4 \%$ at room temperature), and comparable total elongation. Applicable ASTM standards is not available for this type of ODS alloy.

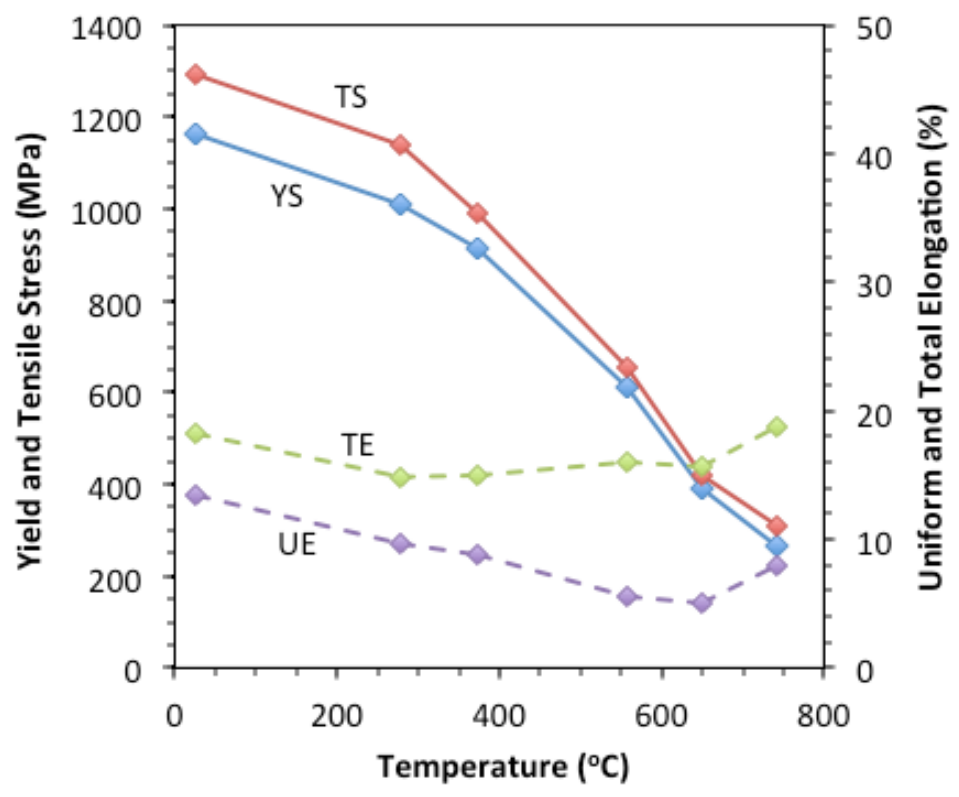

Figure 9. Yield strength, tensile strength, uniform elongation, and total elongation of 14YWT. 
For the alloys to be used at $300^{\circ} \mathrm{C}$, a typical application temperature in LWRs, Figure 10 compares the yield strength (YS) and tensile strength (TS) of the customized Grade 92 (G92) and 14YWT ODS alloy to the down-selected commercial austenitic stainless steels (type 316L and 310), superaustenitic stainless steel (Incoloy 800), Ni-base superalloys (Inconel 625 and 725), and Zirconium alloy (Grade 705 Zr$2.5 \mathrm{Nb})$. Three aspects are deducible from the comparison:

- The ferritic alloys, either tempered martensite G92 or 14YWT, have a small difference in YS and TS, which is comparable to the Zirconium alloy $(\mathrm{Zr}-2.5 \mathrm{Nb})$ and noticeably smaller difference than the Ni-bearing stainless steels and superalloys.

- The G92 has greater strength than the stainless steels and $\mathrm{Zr}-2.5 \mathrm{Nb}$.

- The 14YWT has strength comparable to Inconel 725.

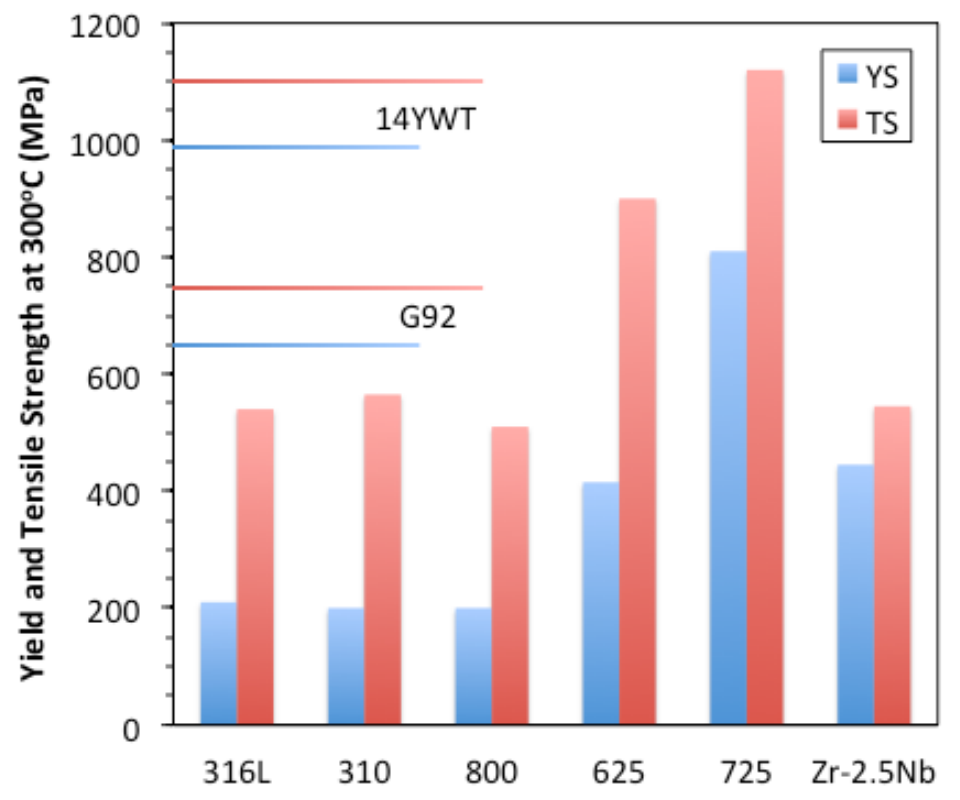

Figure 10. Yield strength comparison of the selected commercial and advanced alloys at $300^{\circ} \mathrm{C}$. 


\section{IMPACT TOUGHNESS OF GRADE 92, 14YWT, AND ALLOY 439}

Charpy impact resistance is an important property of ferritic steels, which influences the application condition of the materials. Charpy impact tests were conducted on a Tinius Olsen Charpy $300 \mathrm{ft}-\mathrm{lb}$ machine according to the ASTM standard E23-12c, "Standard test methods for notched bar impact testing of metallic materials." The measurement calibration of the Charpy machine is performed annually through testing of specimens with certified values to verify the accuracy of the machine. The certified specimens are obtained from the National Institute of Standards and Technology (NIST). Half-size Charpy V-notch specimens with a specification shown in Figure 11 were used to screen the absorbed impact energies at temperatures ranging from $-150^{\circ} \mathrm{C}$ to $300^{\circ} \mathrm{C}$ to determine ductile-brittle transition temperature (DBTT) and upper-shelf energy (USE) of the procured customized Grade 92 (heat 011448), 14YWT, and customized Alloy 439 (heat 011438). The specimens were machined in two orientations, namely the T-L (transverse-longitudinal) orientation with $\mathrm{V}$-notch aligned with the longitudinal direction (heats 011448 and 011438 ) or extrusion direction (14YWT) and the L-T orientation with V-notch aligned with the transverse direction (heats 011448 and 011438 ) or cross-rolling direction (14YWT).

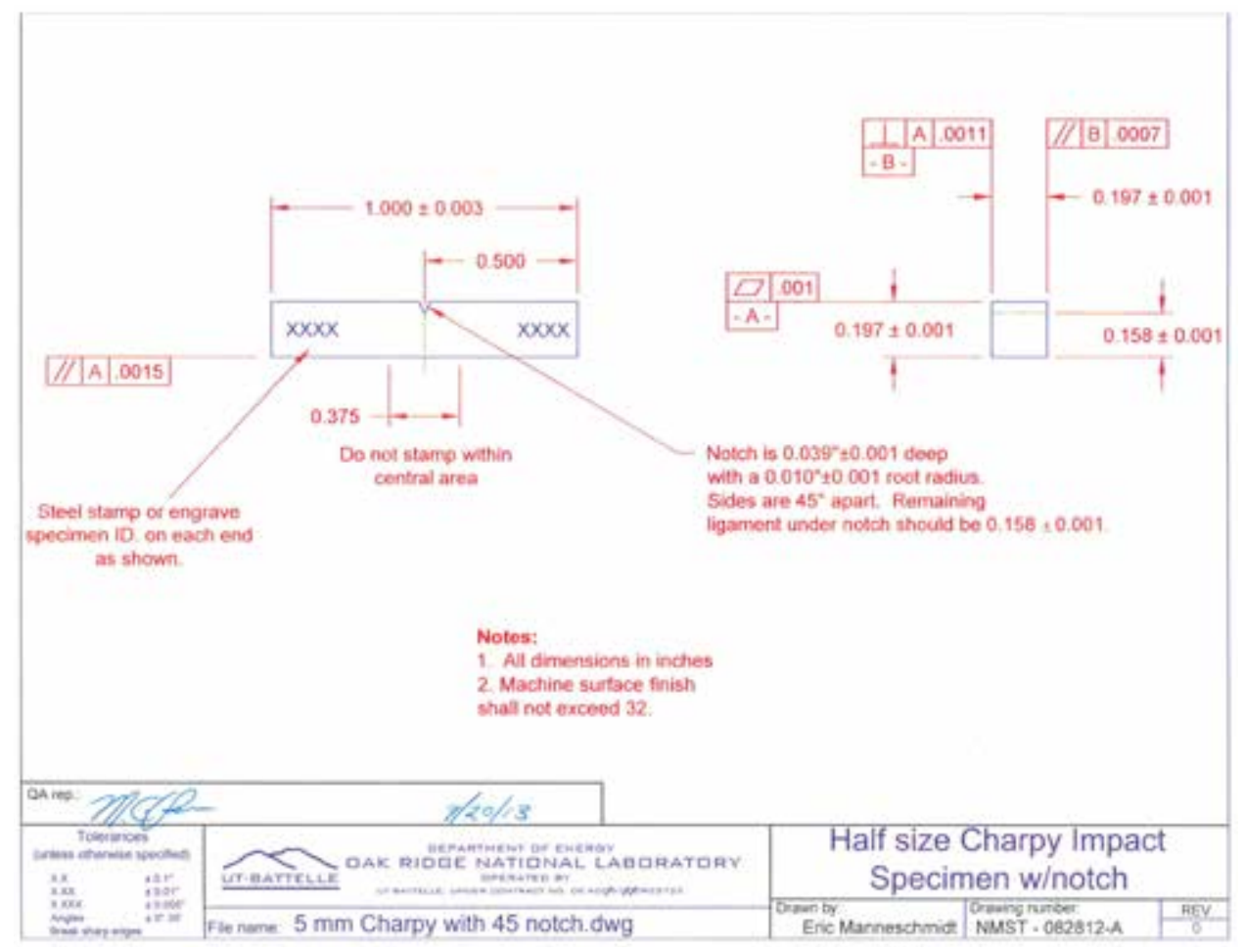

Figure 11. Specification of half-size Charpy V-notch impact specimen.

The tested specimens were extracted from plate \#48X1 of heat 011448 (customized Grade 92). The results are plotted in Figure 12. To obtain DBTT and USE, impact energy-temperature curves were generated by fitting the data with a hyperbolic tangent function $E=a+b \tanh \left[\left(T-T_{0}\right) / c\right]$, where $T$ is test temperature and $a, b, c$ and $T_{0}$ are regression coefficients. In this study, $T_{0}$ is the mathematical DBTT, corresponding to the mean value of USE and lower-shelf energy (LSE), i.e., 1/2USE assuming LSE $=0$ in this study. In comparison, engineering DBTT is determined at $6.5 \mathrm{~J}$ for the half-size specimen $(5 \times 5 \times 25$ $\mathrm{mm})$, lower than the $41 \mathrm{~J}$ for full-size specimen $(10 \times 10 \times 55 \mathrm{~mm})$ [5]. The specimens in the T-L orientation yielded lower USE and higher DBTT than the specimens in the L-T orientation, which is consistent with general observations on specimen orientation dependence. Similarly, the 14YWT 
specimens were primarily tested in the T-L orientation. Two L-T orientation specimens, as shown in Figure 13, exhibited higher impact energies than the specimens in the T-L orientation.

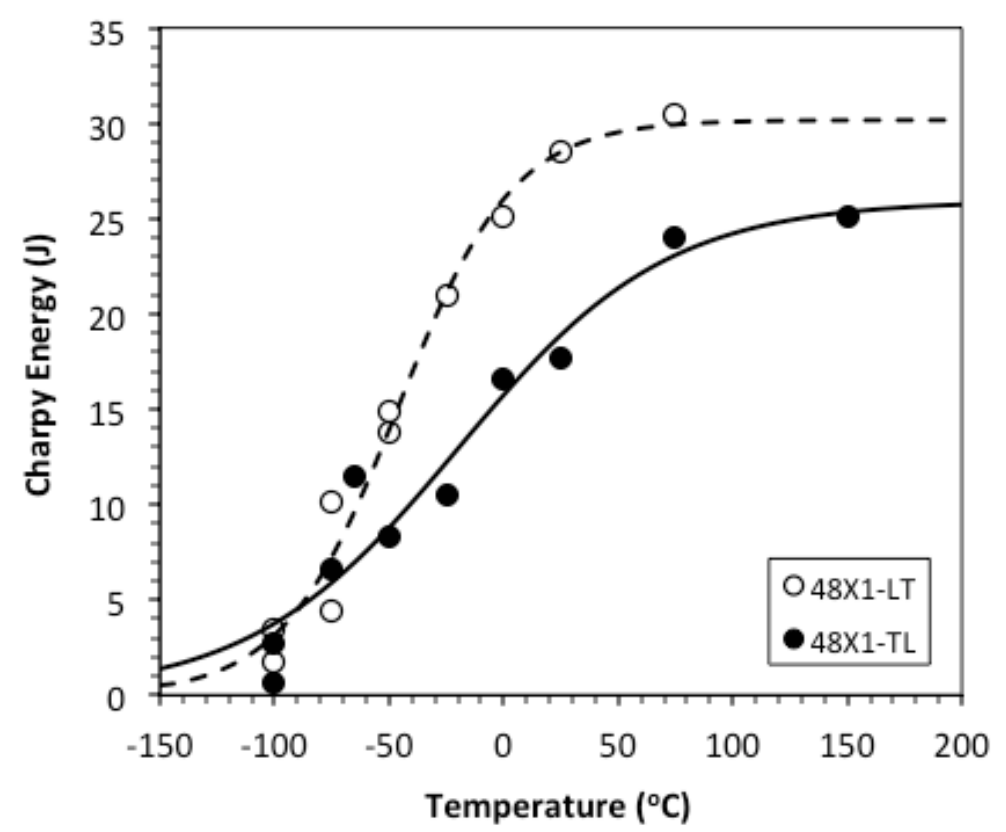

Figure 12. Charpy impact data of customized Grade 92 showing DBTT curves.

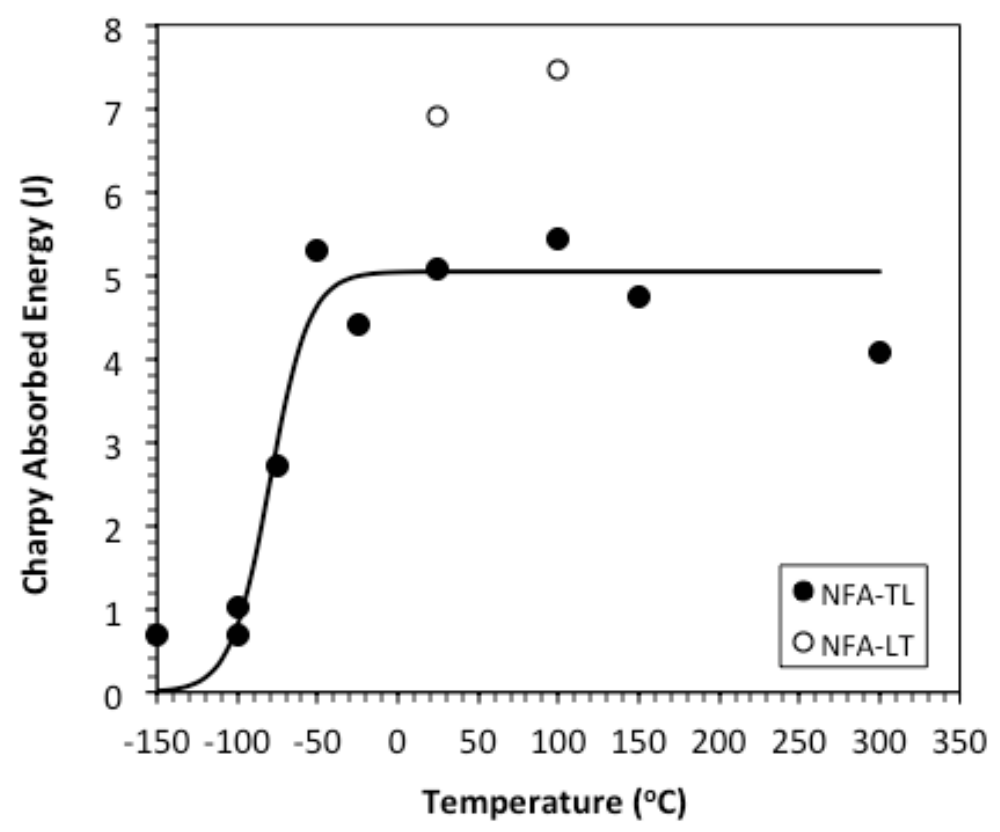

Figure 13. Charpy impact data of 14YWT showing a DBTT curve.

The analyzed results of the customized Grade 92 and 14YWT are summarized in Table 4. As compared to the customized Grade 92, the 14YWT has significantly lower mathematic DBTT at 1/2USE, 
but not available (NA) engineering DBTT at $6.5 \mathrm{~J}$ due to its noticeably lower USE of $5.0 \mathrm{~J}$ (about $1 / 5$ of the USE of the customized Grade 92).

Table 4. DBTT and USE of the tested alloys.

\begin{tabular}{cccc}
\hline Alloy & Mathematic DBTT & Engineering DBTT & USE \\
\cline { 2 - 4 } Sample & $(1 / 2 \mathrm{USE}),{ }^{\circ} \mathrm{C}$ & $(6.5 \mathrm{~J}),{ }^{\circ} \mathrm{C}$ & $\mathrm{J}$ \\
\hline 48X1-LT & -46.1 & -78 & 30.2 \\
48X1-TL & -19.7 & -70 & 25.9 \\
NFA-TL & -79.8 & NA & 5.0 \\
\hline
\end{tabular}

The same type of miniature Charpy V-notch specimens were extracted from the center of the 2"-thick plate \#4 of the customized Alloy 439 (heat 011438). The results are plotted in Figure 14. Due to the large grain size of the as-received condition, only several grains exist in the $4 \times 5 \mathrm{~mm}$ ligament of the miniature specimen, resulting in large variations in the tested specimens. The large variations in the data were observed in the L-T specimens taken from the plate center (LM) in open circles, e.g., the data at 25, 50, and $75^{\circ} \mathrm{C}$, and the $\mathrm{T}-\mathrm{L}$ specimens $(\mathrm{TM})$ in solid circles, e.g., the data at $25^{\circ} \mathrm{C}$. The large variations resulted in the uncertainties of the fitting curves. Basically, the testing results yielded a decent USE of $\sim 43 \mathrm{~J}$, which is $\sim 15 \mathrm{~J}$ higher than the customized Grade 92 and $\sim 38 \mathrm{~J}$ higher than the 14YWT ODS alloy. Although the DBTT of the Alloy 439 is not able to be determined yet, it's likely higher than the customized Grade 92. The grain refinement using the TMT as shown in Figure 4 and the ongoing study using isothermal forging is expected to noticeably decrease the DBTT, which will to assessed in next fiscal year.

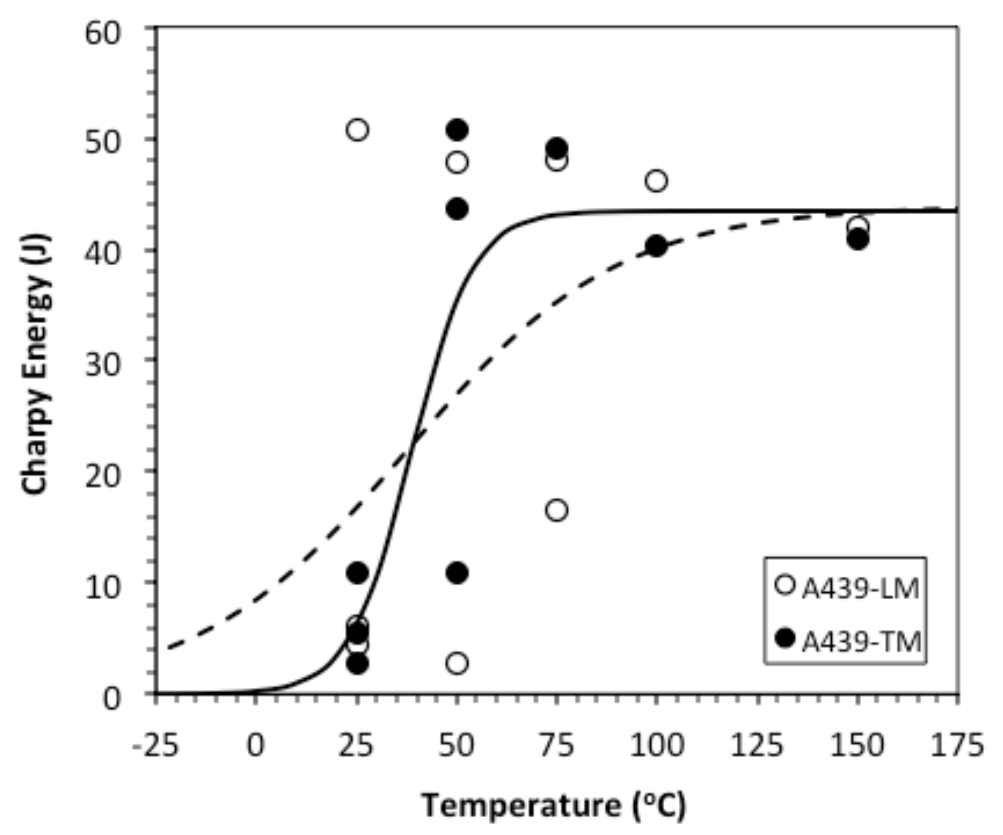

Figure 14. Charpy impact data of the as-received Alloy 439 showing uncertain DBTT curves. 


\section{SUMMARY}

A total of sixteen downselected commercial and advanced alloys have being procured for testing under the ARRM program. EPRI-GE is leading the procurement of eleven commercial alloys. Most of the commercial alloys (nine out of eleven) have been procured. ORNL is leading the procurement of advanced alloys, including customized Grade 92, customized alloy 439, 14YWT ODS alloy, and two other alloys that are to be determined in the alloy groups of $12 \mathrm{Cr}$ ferritic-martensitic (FM) steel and high$\mathrm{Cr}$ and high-Al ODS alloy.

The customized Grade 92, in a form of 2"-thick forged plates with a total of $400 \mathrm{lbs}$. nominal weight, was procured from CarTech, which have acceptable specifications complying with the relevant ASTM standard. The 14YWT ODS alloy was fabricated at ORNL, yielded six plates in a size of 4.72 " $\times 2.76$ " $\times$ 0.35 " per plate with a total weight of $\sim 10 \mathrm{lbs}$. Alloy chemistry at different alloy-making stages exhibited some deviations in oxygen and carbon. The customized Alloy 439 procured from CarTech has abnormally large grain size, ranging from a few hundreds micrometers at plate surfaces to a couple of millimeters at plate center. TMT by means of warm rolling and annealing has been conducted at ORNL. Section of the as-received 2"-thick Alloy 439 plate was subjected to warm rolling to 0.8 "-thick at $300^{\circ} \mathrm{C}$ followed by annealing at $950^{\circ} \mathrm{C}$, which yielded full recrystallization approximately, leading to $\sim 100 \mu \mathrm{m}$ uniaxial grain size across plate thickness and slightly reduced hardness. Application of isothermal forging to the as-received Alloy 439 plates is being investigated to have uniformly refined grains and to approximately retain original 2" thickness. Additionally, reference alloys type $316 \mathrm{~L}$ stainless steel and T91 FM steel were procured. The acceptable quality of type 316 stainless steel to be tested under the ARRM program was determined in terms of the limit of delta ferrite content and grain size uniformity.

Tensile tests were conducted on the procured Grade 92 and 14YWT using type SS-3 miniature specimens at a nominal strain rate of $0.001 \mathrm{~s}^{-1}$ and temperatures from room temperature to $\sim 750^{\circ} \mathrm{C}$ following the ASTM standards E8-13a and E21-09. As compared with the customized Grade 92, the 14YWT exhibited similar temperature-dependent tensile behavior, having noticeably higher strength (e.g., $\sim 410 \mathrm{MPa}$ increase at room temperature and $\sim 130 \mathrm{MPa}$ increase at $\sim 750^{\circ} \mathrm{C}$ ), slightly higher uniform elongation (e.g., $4 \%$ increase at room temperature), and comparable total elongation. The Grade 92 has greater strength than the downselected commercial stainless steels and $\mathrm{Zr}-2.5 \mathrm{Nb}$ alloy at $300^{\circ} \mathrm{C}$, while the 14YWT has strength comparable to the downselected Inconel 725.

Impact toughness of the as-received Grade 92, 14YWT, and Alloy 439 was evaluated using half-size Charpy V-notch specimens in the T-L and L-T orientations at temperatures from $-150^{\circ} \mathrm{C}$ to $300^{\circ} \mathrm{C}$ following the ASTM standard E23-12c. Specimens in the T-L orientation generally exhibited lower upper-shelf energy (USE) and higher ductile-brittle transition temperature (DBTT) than the specimens in the L-T orientation. As compared to the Grade 92, the 14YWT has significantly lower mathematic DBTT at $1 / 2 \mathrm{USE}\left(-79.8^{\circ} \mathrm{C}\right.$ of the $14 \mathrm{YWT}$ vs. $-19.7^{\circ} \mathrm{C}$ of the Grade 92$)$, but does not have applicable

engineering DBTT at $6.5 \mathrm{~J}$ for this type of subsize specimens because the USE of the 14YWT is $5.0 \mathrm{~J}$ (in contrast to $25.9 \mathrm{~J}$ of the Grade 92). The engineering DBTT of the Grade 92 was $-70^{\circ} \mathrm{C}$ of the T-L specimens. The experimental data of the 14YWT followed a good consistent trend as a function of testing temperature, which may suggest that the observed pores, stringers of small dark particles, and some bimodal grain size distribution in the 14YWT did not result in significant effect on the impact toughness results. The DBTT of the Alloy 439 was not able to be determined yet due to the large variations of the tested specimens, which may be attributable to the limited numbers of grains within the testing ligament of the half-size specimen. The USE of the Alloy 439 was determined to be $\sim 38 \mathrm{~J}$. The effect of grain refinement by the TMT and ongoing isothermal forging on the impact toughness will be pursued in next fiscal year. 


\section{REFERENCES}

[1] E.A. Kenik, J.T. Busby, Radiation-induced degradation of stainless steel light water reactor internals, Mater. Sci. Eng. R 73 (2012) 67-83.

[2] F.A. Garner, Radiation damage in austenitic steels, in: R.J.M. Konings, T.R. Allen, R.E. Stoller, S. Yamanaka, Comprehensive Nuclear Materials, Elsevier, The Netherlands, 2012.

[3] Critical Issues Report and Roadmap for the Advanced Radiation-Resistant Materials Program, EPRI, Palo Alto, CA and the U.S. Department of Energy, Washington, DC: 2012. 1026482.

[4] L. Tan, D.T. Hoelzer, J.T. Busby, Microstructure and basic mechanical properties of the procured advanced alloys for the advanced radiation resistant materials program, ORNL/TM-2014/439, Sept. 22, 2014.

[5] M.A. Sokolov, R.K. Nanstad, On impact testing of subsize Charpy V-notch type specimens, in: D.S. Gelles, R.K. Nanstad, A.S. Kumar, E.A. Little (Eds.), Effects of Radiation on Materials: $17^{\text {th }}$

International Symposium, ASTM STP 1270, 1996, pp. 384. 